\title{
Information highways: A threat to democracy?
}

Marie d'Udekem-Gevers ${ }^{1}$

Cellule Interfacultaire de Technology Assessment (CITA)

Institut d'Informatique, Facultés Universitaires Notre-Dame

de la Paix, Rue Grandgagnage, 21,

B-5000 Namur, Belgium

Phone: + 328172 4973, Fax: + 3281724967

Email:mgevers@info.fundp.ac.be

\begin{abstract}
This paper focuses on the potential impacts of the information highways on democracy. It begins by showing with concrete examples that this new technology, like other communication networks, is a tool which allows integration and cohesion to be increased. But the paper stresses that to improve communications does not mean making society more equal and more democratic. The second part of this paper considers how to build up the information highways according to official documents of the European Union. It underlines that the liberalization of the telecommunications sector required by the official texts and the basic importance given to market forces and to competition can be considered a threat to democratic values. There is a serious risk of increasing inequalities. There are also problems linked to services and to content such as issues in financing nonprofit services, threats to the freedom to communicate and to operate on the network, risks of information being limited, and so on.
\end{abstract}

\section{INTRODUCTION}

Information highways (IH) are defined here as the international broadband networks projected by governments in most economically developed countries. Such networks (or more probably networks of networks) will be able to transmit numerical and multimedia information and will allow interactivity. They are examples of new information and communication technologies (ICT). 
They are considered, particularly in the European Union $(E U)^{2}$, as leading to the emergence of the information society (IS). While the last expression is more frequently used in EU documents than in those on the IH, both are considered here as referring to the same framework of reflection.

In this paper, the main question is that of evaluating the risks of the $\mathrm{IH}$ for democracy ${ }^{3}$, particularly, for democratic values i.e., consensus values on which any democracy is based. The democratic process itself (for example, the mechanism of representative and direct democracies) will not be discussed here.

\section{A CHANCE FOR DEMOCRACY?}

\section{Opportunities offered by the information highways}

Like any communication network, information highways (IH) are tools which allow social integration and cohesion to be increased via communications. Moreover, thanks to the access to information and databases, the IH can also contribute to levelling society. Thus, they could help the democratic basis for society to be enforced.

Indeed, analysis of existing communication and information networks (such as the Internet and Freenets) shows that they produce the emergence of new ${ }^{4}$ community concepts. Practically, new communities based on ICT can be classified into two types on the basis of their extension in space: local communities and scattered communities. According to Beamish's vocabulary (1995), the first type is most often named either community network or civic networking and the second type, virtual community or online community.

"A "community network" is a network of computers and modems that are interconnected via telephone lines to a central computer. The system provides local information and a means for community residents to communicate electronically. (...) Community networks are located and support a specific physical place' (Beamish 1995, Abstract). A community network characteristic is 'the belief that the system, and its communication and information, can strengthen and vitalize existing communities... It is believed that community networks can be used by the local community to find and build solutions to their problems' (Beamish 1995, p. 2). 'Increased communication and information will increase the sense of community, increase involvement in the community, and serve as a tool to solve some of the problems facing the community at a grass-roots level... Community networks will improve democratic governance and empower citizens to become more active and informed ${ }^{5}$ (Media Access Project 1994)' (Beamish 1995, p. 3; emphasis added). The first community network was created in Berkeley during the mid-1970s. Since this period, these networks have grown in number in the United States (US). And, ever since 1993, they can receive public funding. In Europe, Application Ten of the Bangemann Report, named City Information Highways and suggested by Hervé (1996a, p. II), corresponds to some extent to the concept of community networks. In this framework, trials are currently being undertaken in six selected cities (Naestved, London, Eindhoven, Venice, Trieste, and Bologna) (see Kooi, 1996). Among other examples, let us also mention the European projects of digital cities called METASA and MIND (Hervé, 1996a p. V, VIII, IX) 
involving Parthenay (France), Arnedo (Spain), Weinstadt (Baden-Wurttemberg Land) and Torgau (in the former East Germany). The case of Parthenay is particularly worth a mention: in this little city, the concept of active citizenship as defined by Hervé ${ }^{6}(1996 \mathrm{~b}$, p. 18) is being put forward and reinforced via telecommunication networks. Another famous European example is De Digitale Stad Amsterdam?

An online community is 'a social group of any size that shares common interests, whether those be social, professional, occupational, or religious ... They gather together electronically in newsgroups or mailing lists to discuss specific topics which range from academic research to hobbies. There are no geographic boundaries to on-line communities and participants can be located anywhere in the world' (Beamish, 1995, p. 6). Examples of online communities are very numerous and different. Jerusalem One, for instance, is a network which allows the Jewish diaspora to keep in touch. Via the Association for Progressive Communications (APC) network, a virtual community of more than 20,000 non-governmental organizations (NGOs) from poor countries can now hold discussions and be heard by people in rich countries (see Afonso, 1994, and Bissio, 1994). Let us remark that participating in an electronic forum can be really democratic: all the opinions can have the same weight, from the point of view of visual presentation (Bissio, 1994).

Outside these new types of communities, social cohesion can be improved via the IH if the possibility of communicating (particularly the possibility of expressing oneself and of producing information) and/or of accessing information (particularly in the domains of education, health, and/or administration and public information) is given to people previously excluded or disenfranchised; groups at risk (such as women, disabled people, the elderly, the unemployed, the homeless ${ }^{8}$ ); minorities, isolated or poor regions, or less favoured countries. Let us take the case of women, for example. 'The new media actually provide many new vehicles for women to redress imbalances. In cyberspace, no one needs to know what gender you are. Furthermore, research has shown that the new media provide opportunities to overcome gender differences. Computer conferencing ... and Net discussion groups have been found to change criteria for leadership - moving the most succinct (often women), rather than the forceful and verbose, to the fore ... And as for women who choose to be homemakers, the I-way can reduce rather than increase isolation and stratification' (Tapscott 1996, p. 295). As summarized by Tapscott (1996, p. 294), technology can be a great leveller.

'Overall, then the capacity that information and communication technologies offer to put individuals and groups in contact with one another to request a service, to exchange knowledge, to transmit information and so on, promotes participation in community life and a renewal of sociability which are necessary to effective democracy' (High Level Expert Group on the IS, 1996, p. 78; emphasis added).

\section{Status of the information highways}

But the fact is that, while the IH do offer these possibilities, they do not automatically result in improving social cohesion! And the idea of brotherhood and equality brought by a communication network is nothing other than a utopia. 
Nevertheless it is frequent and old. '... The creation of a network of networks ... will bring ... strong democracies ...' Gore states (1994), for example. As pointed out by Mattelart (1995a and 1995b), this kind of utopia has appeared since 1793, with the installation of the optic telegraph between Paris and Lille. It re-emerges whenever communications (either transport or signal transmission) show a major technological leap (Mattelart, 1995b). For example, in 1832, Michel Chevalier, a disciple of Saint-Simon, after observing the installation of the first railway in England, wrote that communication decreases distances between different points but also between social classes. And he concluded that to improve communications means thus to make society more equal and more democratic. According to Mattelart's analysis, the same idea is used by Wiener in 1948 (with the information society) and by McLuhan in 1960 (with the global village).

But communication, by itself, is not social progress (Ramonet, 1996). And the IH, like other ICT, are only instruments: they can be used either positively or negatively! Not only NGOs but also racist or paedophile associations can profit from their possibilities. Moreover, the IH offer an opportunity to reduce social disparities if and only if everybody has access. This sine qua non condition implies, in turn, that there is a political will for equity and that the laissez-faire conditions suggested by the global market economy are seriously counterbalanced. As we are going to see now, it is far from being established.

\section{HOW TO BUILD THE INFORMATION SOCIETY ACCORDING TO EUROPEAN UNION OFFICIAL DOCUMENTS}

Let us thus have a look at the history of the information society in Europe and in European Union official documents.

After the publication in 1993 of the Commission of the European Communities (CEC) White Paper, Growth, Competitiveness, Employment - The challenges and ways forward into the 21 st century, the Council requested that a group of prominent persons from the private sector (members of the executive staff of such firms as Bull, Canal Plus, Olivetti, La Société Générale de Belgique) prepare a report on the IS. This report, issued in May 1994 and entitled Europe and the global information society - Recommendations to the European Council is generally referred to as the Bangemann Report. It includes the following sentences: 'The market will drive ... the prime task of government is to safeguard competitive forces ...' (p. 9; emphasis added). 'The Group recommends member States to accelerate the ongoing process of liberalization of the telecom sector by opening up to competition infrastructures and services still in the monopoly area ...' (p. 12) 'The group believes the creation of the IS in Europe should be entrusted to the private sector and to market forces ...' 'There will be no need for public subsidies, because sufficient confidence will have been established to attract the required investment from private sources' (Bangemann, et al, 1994, p. 30).

All these statements can be considered as reflecting the main principles of neoliberalism.

In its action plan (Com (94) 347 final) which was published in July 1994 and is the basic official document about the IS, the CEC supports the conclusions of the Bangemann Report and concludes (p. 4): 'The Community will assume its 
responsibilities for setting the appropriate regulatory environment. In parallel, the private sector is invited to play its entrepreneurial role and launch without delay concrete initiatives for the prompt deployment of the IS'. Moreover, an important characteristic of this action plan is the little concern paid to the social dimension of the IS. Emphasis is essentially on economic issues and goals. Let us note that, from this point of view, the action plan contrasts with its US equivalent: the National Information Infrastructure: Agenda for Action (IITF, 1993). In the latter, the economic and social aims of the IH have the same priority.

The insufficient concern about the social issues and goals of the IS in the EU is so clear that it has been denounced and underlined by both reflection groups created in 1995 in the framework of the action plan itself (ISPO, 1995). Indeed the High Level Expert Group on the $\operatorname{IS}^{9}(1996$, p. 1) remarks: 'So far, the IS policy debate has been dominated by technological issues and more recently the appropriate regulatory economic environment, neglecting by and large, some of the broader issues implicit in the society notion'. As for the IS Forum ${ }^{10}(1996 \mathrm{~b}, \mathrm{p}$. 10 ), it declares that more needs to be done to assert the moral and social dimension of the IS and also states that questions of public and individual interest, of setting social and professional standards, and of defining objectives which sustain democratic and individual liberties should be regarded by the European Commission as of equal importance as the need to foster the conditions for economic exploitation.

But it seems that things could improve now. While the CEC does not recognize its past lack of social concern ${ }^{11}$, it has recently written (on July 24, 1996) a Green Paper entitled Living and Working in the IS: People First in order to promote wide discussion and awareness of the social and societal issues involved (see Com (96) 389 final, p. 4). But this paper is far less precise than those of both reflection groups, and looks like a catalogue of pious wishes. And there is another, perhaps more promising, sign: the Commission (see Com (96) 395, final and Com (96) 607) has defined four new priorities to be taken into account, among which, people first. Moreover, it has explicitly declared (see Com (96) 395 final, p. 1a) that all these priorities have the same importance. After these promises, let us wait now for the facts.

\section{A THREAT TO DEMOCRACY?}

Let us now tackle the main question asked in this paper: are the information highways a threat to democratic values? The answer is that, when implemented within the framework of deregulated global markets and with weak concern for social issues, this new technology could become threatening to democracy.

\section{Conflicting principles}

Indeed, the rules of the market do not overlap with those of democracy (see Table 1). To be clearer, let us give concrete expression to the main principles of democratic ethics: let us choose here to consider, for example, freedom of all human beings, equality and fraternity. To these three basic values, let us add a less romantic one: efficiency. This last principle is of course also at the basis of 
neoliberalism (as of any other economy theory). But the three others characterize democracy. Corresponding values from some liberal leanings (such as those of the Chicago School) are fully justified by efficiency in the framework of the global market. They could be defined respectively as follows: freedom of enterprises to trade, inequalities based on income differentials and, last but not least, competitiveness. They are opposed to democratic values.

Table 1: Comparison of principles of the democratic ethics and rules proposed by some global market economy advocates

\begin{tabular}{ll}
\hline Principles of democratic ethics & $\begin{array}{l}\text { Rules proposed by some global market } \\
\text { economy advocates }\end{array}$ \\
\hline Freedom of all human beings & Freedom of enterprises to trade \\
Equality of all human beings & Inequalities based on income differentials \\
Fraternity of all human beings & Competitiveness \\
Efficiency & Efficiency \\
\hline
\end{tabular}

\section{Factual risks}

If access to the IH is based only on market laws, and information is considered as a marketable good, two major classes of issues for democratic principles arise, linked to access and linked to content.

Let us note that all these issues are increasing because, in the framework of the globalization and of the convergence of telecommunication/computer science/audio visual sectors, huge enterprises and conglomerates which vertically integrate the production and distribution of content are now being set up.

\section{Issues linked to access}

The Declaration of Human Rights ${ }^{12}$ states that everyone has the right of equal access to public service in his or her country. A new version of public service called universal service is proposed in the EU as an essential element of the IS (see title of Com (96) 73 final). Universal service means a defined minimum set of services of specified quality which is available to all users independent of their geographical location and, in the light of specific national conditions, at an affordable price (Com (96) 419, p.9). As underlined by Hercberg (1996) and Barrère (1996), this definition is imprecise and very restrictive. Moreover, it must be noticed that the crucial question of affordability is left to member states. 'With the adoption by the European Parliament and the Council of the Voice Telephony Directive in December $1995^{13}$, the Community has now for the first time identified the common scope of universal service obligations in the EC ... The obligations ... comprise the provision of voice telephony service via fixed connection which will also allow a fax and a modem to operate as well as the provision of operator assistance emergency and directory enquiry services ... and the provision of public payphones. Users should also have access to published information about the cost and prices of services, about their quality and whether targets for quality are being met. By including network access within the scope of universal service, users are 
given the possibility of accessing not only the defined voice telephony service but all services that can be provided over today's telecommunications networks (i.e., every citizen will be able to access interactive and on-line information services including the Internet, provided they have a computer and a subscription with an Internet service provider)' (Com (96) 73 final, pp. 4-5). This definition of scope shows clearly that access is unfortunately limited to technical means, thus to the pipeline $^{14}$, and does not extend to the content, that is, to specific information (except about costs and prices) and specific services (such as, for example, community services). The IS Forum does not agree with this definition and recommends universal public access to basic online services such as public information, education, and health (IS Forum 1996a, p. 5).

Moreover, in a liberalized environment, financing universal service is not easy and offering an affordable price to all users looks somewhat problematic, mainly in the short term. Issues appear at the level of the current basic telephone service and at the level of the new services of the IH. Indeed, on the one hand, telephone bills could rise for residential consumers (who make few long-distance and international calls) because of the process of tariff rebalancing resulting from political decisions in favour of the liberalization of the sector (Com (96) 73 final, p. 9). This trend is already evident on the scale of the whole EU for the period 1990-1995: the available data 'shows that important changes in tariff structures are underway, and, in particular, the general trend of increases in fixed elements in the tariffs ... (connection and rental), as well as higher charges for local calls at peak hours and in most Members States, corresponding reductions in regional, long distance and international calls' (Com (96) 73 final p. 41; emphasis added). Let us remark also that deregulation in the US produced a shortening of two points in the rate of telephone connection (see Torres, 1996). On the other hand, 'the new services will mostly be financed by subscriptions and could be an expensive item for consumers'; thus, access at affordable prices is by no means guaranteed (IS Forum 1996a, p.15).

As a result, there is a risk of increasing inequalities: society could now be divided between information haves and have nots (or perhaps also between information wants and want nots). This risk is frequently denounced and generally considered as the greatest one in the IS (see, for example, IS Forum 1996b, p. 9). As pointed out by Mansell (1995, p. 50), as liberalization and competition take hold, the supercarriers will continue to pursue their goals in international markets and they will become increasingly reluctant to bear public service responsibilities. However, in the interest of both equity and efficiency in the market, there is a need to ensure that a common public network continues to evolve. The risk of increasing disparities ${ }^{15}$ does exist at several levels: inside society in industrial countries, between regions (for example, of the EU) and, obviously, between North and South.

Inside society in the industrial countries, several groups are threatened as excluded from information. These groups ${ }^{16}$ have been listed by the High Level Expert Group on the IS (1996, p. 34) as follows: people with reduced mobility or impaired physical ability to communicate, the elderly, early and active retired persons, low income families, the unemployed, women, persons with learning disabilities, and illiterate people. Let us note this remark of Tapscott (1996, p. 296): 'As for differences between old and young, there is little doubt that the 
generation of 10- to 25-year olds, are effortlessly embracing the new media. Rather than a generation gap, there is a danger of generation lap where cyberspace is part of life of one generation and an uncomfortable place for preceding ones'.

Existing inequalities between regions of the EU are well known. For example, the whole of European scientific innovation is considered to be concentrated in ten islands (see Hilpert, 1991): the south-east of England, Paris/Ile-de-France, Frankfurt, Munich, Turin, Rotterdam/Amsterdam, Rhine-Ruhr, Stuttgart, Lyon/ Grenoble, and Milan. The Commission itself recognizes (Com (96) 389 final, p. 21) that 'disparities between regions within the same Member State have tended to widen over time'. There is some evidence that disparities are currently still growing. Indeed, as pointed out by the High Level Expert Group (1996, p. 42), the pace of liberalization of the telecommunications market in the less-favoured regions of the EU seems to be now less rapid than in the core regions. In the future, the risk of increasing inequalities between regions is perhaps higher yet. Indeed, ' $\cdots$ given the deregulation and privatization of telecommunications, information and communication technologies services will be provided on a commercial basis thus raising, on the one hand, the question about the commercial viability of privatized telecom services in less-favoured regions and, on the other hand, the risk that only the more affluent and/or core regions will benefit from the more competitive pricing and new services following liberalization' (High Level Expert Group on the IS, 1996, p.41). In other words, 'a major concern is that commercial or market forces may lead to a concentration of investment in geographical areas which appear to be the most profitable ...' (IS Forum 1996b, p.17). Let us remark that the CEC is perfectly aware of the issues of access to the IH. After its Communication on universal service for telecommunication (see Com (96) 73), it declares (see Com (96) 389, p. 22): 'there remain important questions concerning the level and quality of access of less favoured and less populated regions, groups with special needs, and public institutions ... to the full range of IS service'.

The problem of increasing inequalities between the world's North and South is still more worrying. Recent indicators (UNDP, 1996) show that the gap between rich and poor countries is widening. United Nations Development Programme administrator, J. G. Speth, concludes: 'If present trends continue, economic disparities between industrial and developing nations will move from inequitable to inhuman' (The Straits Times, July 17, 1996). As clearly underlined by Renaud (1996, p. 94), there are three serious obstacles to the IH in the less developed countries: the lack of solvency, insufficient infrastructures, and the widespread illiteracy. Thus, the development gap is probably going to become still wider. The southern countries were unfortunately not invited to the G7 summit of February 1995 on the information society in Brussels. To try to compensate for this absence, another G7 meeting devoted to information society and development was organized with the participation of thirty developing countries in May 1996 in South Africa. But, at this summit, most of the poorest countries (which are generally also less connected to worldwide telecommunications networks - see Elie, 1996) were not represented. According to the conference theme paper: 'Even in the developing countries, the private sector should be primarily responsible for financing the development of the IS' (ISAD Conference - press information, 1996). Moreover, the South was encouraged to open its countries to the global market. 
But, once open to competition, the poor countries (particularly in Africa) could be threatened by delocalized telecommunications infrastructures (see Renaud, 1996, p. 95): indeed low earth orbit satellites (for example, the Iridium satellites now built at Motorola, Arizona) could be used. And this, in turn, could be a new risk for development, as Renaud (1996, p. 95) remarks. Indeed, on the one hand, the financing of local infrastructures could be more difficult and, on the other hand, more qualified jobs could also be delocalized.

\section{Issues linked to content}

As to the issues for democracy linked to the services and the content of the IH in the framework of pure neoliberalism, they are numerous.

First of all, the question of how to finance nonprofit services (such as education, help to people, health) can be asked. The public's need for online services is unlikely to be fully satisfied by market forces (IS Forum 1996a, p.17). Thus the democratic principle of fraternity (or solidarity) is likely to be neglected.

Other issues are threats to freedom of any human being. Indeed, the freedom to communicate $^{17}$ and to operate (i.e., use services, etc.) on networks is generally endangered. Privacy and freedom from intrusion are threatened. As pointed out by the IS Forum (1996a, p. 11), there is a strong commercial interest in monitoring online activities and the transactions of citizens, building detailed consumer profiles which can then be used for a wide range of purposes (such as marketing or credit decisions) for which the data were never intended. New techniques developed by Webtrack, NetCount or Internet Profiles, called I/PRO, already allow the manager of an Internet site to know by whom the site has been visited (see Stagliano, 1996, p. 92). There is also a risk of being flooded with stupefying entertainment programmes, needless gadgets and useless services. This is already illustrated by what happens in trial projects on the IH made by consortiums of firms in various cities (for example, Orlando, Omaha (Nebraska), Castro Valley (California), Alexandria (Virginia)) around the US. As reported by Johnson (1996, p. 15-16), executives from Time-Warner, Inc. are proudly showing a video about the Full Service Network currently being tested in Orlando, Florida. The video shows happy suburban families using their set-top boxes to play games, watch movies, browse electronic magazines, and order pizzas and bedroom sets. There is also a danger of being overrun with advertisements. Moreover, the quality and the diversity of the information is also likely to be threatened: this is underlined by both the IS Forum (1996b, p. 13) and by the High Level Expert Group on the IS (1996, pp. 70-71). 'With the deregulation and internationalization of [ICT] industries, the abilities of individual governments to impose standards of practice on communications providers in the IS is significantly weaker, whilst the risk of information terrorism and political manipulation paid for by influential groups or companies grows' (High Level Expert Group on the IS, 1996, p. 78). There is a risk that information circulating on the highways is limited (for example, to the sensational and spectacular), distorted, and no longer pluralistic. And, as pointed out by Dolhem (1996), this threat exists here and now. Dolhem (1996) gives as proof the current struggle of Microsoft, the software champion, to offer content: after launching the cyberspace news magazine called Slate, Bill Gates' firm has recently joined with the National Broadcasting Company (NBC), the most important US television channel. Both firms have invested nearly one billion US dollars to create 
a new network mixing television and computer, and have begun to broadcast continuous news since July 15, 1996. Moreover Bill Gates has announced a new online newspaper on the web, Cityscape, which will give pieces of information on the big US cities. To sum up, if political power is left to business groups, these groups could push for an information superhighway that delivers much less public benefit but maximizes their own projected benefit (Johnson 1996, p. 17). Thus, there is a risk of being treated as consumers to be targeted rather than citizens to be connected (Johnson, 1996, p. 16). There is a danger of a large-scale enslaving of minds (Schiller, 1994).

\section{CONCLUSION}

The analysis of official documents related to the information society shows that current European Union policy focuses mainly on competitiveness and pays far less concern to social issues than to economic challenges. In this framework, implementation of the information highways could become a threat to principles of consensus such as freedom, equality, and the fraternity of all human beings.

'While markets must drive most developments, public interest must be safeguarded' (The IS Forum, 1996a, p. 12). Thus, while encouraging the market, governments and public authorities at all levels must also act as active guarantors of democratic values. As suggested by the IS Forum, they must show a greater readiness to assume their responsibilities in this matter.

Only when this condition is met, will it be possible to target the European model defined by the European Commission (Com (96) 389 final, p. 30) as built both on competition between enterprises and solidarity between citizens and member states.

\section{ACKNOWLEDGEMENT}

The author wants to thank Renaud Delhaye and Domenico Rossetti di Valdalbero for their corrections and suggestions, and Claire Lobet-Maris for her comments.

\section{REFERENCES}

Afonso C.-A. 1994, Réseaux électroniques et action politique au service de la société civile, Le Monde Diplomatique, juillet 1994.

Bangemann M. et al. 1994, Europe and the global information society - Recommendations to the European Council, CD-84-94-290-EN-C, Brussels, 26 May 1994, 36 p.

Barre Ch. 1996, Citoyens, ou... nécessiteux? Le Monde Diplomatique, janvier 1996.

Beamish A. 1995, Communities On-Line: Community-Based Computer Networks, submitted to the Department of Urban Studies and Planning in partial fulfillment of the requirements of the degree of Master in City Planning at the Massachusetts Institute of Technology, February 1995.

Bissio R. 1994, Cyberespace et démocratie, Le Monde Diplomatique, juillet 1994.

Commission of the European Communities 1993, White Paper - Growth, Competitiveness, Employment - The challenges and ways forward into the 21st century.

Commission of the European Communities 1994, Europe's Way to the Information Society. An Action Plan-Communication from the Commission to the Council and the European Parliament and to 
the Economic and Social Committee and the Committee of Regions, Com (94) 347 final, Brussels, 19.07.1994.

Commission of the European Communities 1996, Universal Service for Telecommunications in the Perspective of a Fully Liberalized Environment - An Essential Element of the Information Society, Com(96) 73 final, Brussels, 23.03.1996.

Commission of the European Communities 1996, Green Paper - Living and Working in the Information Society: People first, Com (96) 389 final, Brussels, 24.07.1996.

Available at http://www.ispo.cec.be/infosoc/legreg/cdocs/people1st.htlm

Commission of the European Communities 1996, Information Society: from Corfu to Dublin - The New Emerging Priorities Com (96) 395 final, Brussels, 24.07.1996.

Commission of the European Communities 1996, Europe at the Forefront of the Global Information Society: Rolling Action Plan - Communication from the Commission to the Council and the European Parliament and to the Economic and Social Committee and the Committee of Regions, Com(96) 607 final, Brussels, 27.11.1996.

Com (96) 419 1996, ONP VT Directive XIII/96/53 rev3, Proposal for a European Parliament and Council Directive on the application of ONP to voice telephony and on universal service for telecommunications in a competitive environment, 11 September 1996.

Dolhem N. 1996, Télécybervision, Le Monde Diplomatique, août 1996, p. 19.

Elie M. 1996, Internet et développement - Un accès à l'information plus équitable? Futuribles, Novembre 1996, pp. 43-64.

European Parliament and Council 1995, Directive 95/62/EC on the application of Open Network Provision (ONP) to Voice Telephony (the Voice Telephony Directive), OJ L321.

FCC (Federal Communications Commission) 96J-3 1996, In a Matter of Federal-State Joint Board on Universal Service - Recommended Decision, Adopted: November 7, 1996, Released: November 8, 1996, CC Docket No. 96-45.

Gore Al 1994, Plugged into the world's knowledge, Financial Times, September 19, 1994.

Groupe de Lisbonne 1995, Limites à la compétitivité - Pour un nouveau contrat mondial, Editions La Découverte, Paris, février 1995, 227 p.

Hercberg S. 1996, Des services publics garantis de l'intérêt général, Le Monde Diplomatique, juin 1996, pp. 8-9.

Hervé M. 1996a, Autoroutes de l'information urbaines - Le défi du partenariat public/privé, City Information Highways Workshop, Evolution, Eindhoven, 22 mai 1996.

Hervé M. 1996b, Changer la ville!, Transversales Science Culture, 41, pp. 14-19.

Hilpert 1991, Archipelago Europe, mentioned in Hingel A.J. 1993, Note sur un nouveau modèle de développement européen, La Prospective - FAST, CCE, FOP 361, pp. 21-23.

High Level Expert Group on the Information Society 1996, Building the European Information Society for us all - Interim Report, January 1996, available at http://www.ispo.cec.be/hleg/hleg.htlm

IITF (Information Infrastructure Task Force) 1993, The National Information Infrastructure: Agenda for Action, September 151993.

Information Society Forum 1996a, Networks for People and their Communities - Making the Most of the Information Society in the European Union - Fist Annual Report to the European Commission from the Information Society Forum, June 1996.

Information Society Forum 1996b, Networks for People and their Communities - Making the Most of the Information Society in the European Union - Fisrt Annual Report to the European Commission from the Information Society Forum - Supplement Containing Groups Reports, June 1996, available at http://www.ispo.cec.be/

ISAD (Information Society and Development) Conference - South Africa, 13-15 May 1996 Press information.

ISPO (Information Society Project Office) 1995, Europe's Way to the Information Society, Updated Version of the Action Plan, Status of the 15th December 1995.

Johnson J. 1996, The Information Superhighway: a Worst-Case Scenario, Communications of the $A C M$, February 1996, 39 (2), pp. 15-17.

Kooi A. 1996, City Information Highways: an assessment of on-going projects, City Information Highways Workshop, Evolution, Eindhoven, 22 mai 1996.

Mansell R. 1995, From telephony to telematics: equity, efficiency and regulatory innovation, in Information Superhighways - Multimedia users and futures, Emmot S.J. Ed., Academic Press 1995, pp. 35-60.

Mattelart A. 1995a, Les nouveaux scénarios de la communication, Le Monde Diplomatique, août 1995, pp. 24-25. 
Mattelart A. 1995b, Une éternelle promesse: les paradis de la communication, Le Monde Diplomatique, novembre 1995, pp. 4-5.

Media Access Project and People for the American 1994, A Proposal to Improve Democratic Governance via the National Information Infrastructure. Draft.

Miller P. 1996a, The Building Blocks of Electronic Democracy, The CPSR Newsletter, 14 (2), pp. 1-2 and 18-19.

Miller P. 1996b, CTCNet and the Movement for Democracy, The CPSR Newsletter, 14 (2), pp. 5 and 21.

Ramonet I. 1996, Changer d'ère, Manière de Voir, Hors-série (Le Monde Diplomatique), octobre 1996, pp. 6-7.

Renaud P. 1996, L'avenir informatique du Sud, Manière de voir, Hors-série (Le Monde Diplomatique), octobre 1996, pp. 94-95.

Schiller H.I. 1994, Reléguer le bien public sur les bas-côtés, Le Monde Diplomatique, mars 1994.

Schuller D. 1996, Democracy and Democracyware, The CPSR Newsletter, 14 (2), pp. 10-15.

Sérusclat F. 1995, Les nouvelles techniques d'information et de communication: l'homme cybernétique?, Office Parlementaire d'Evaluation des Choix Technologiques, Tomes 1 and 2.

Stagliano R. 1996, Publicité du troisième type, Manière de Voir, Hors-série (Le Monde Diplomatique), octobre 1996, pp. 91-92.

Torres A. 1996, Une nouvelle proie, les télécommunications, Le Monde Diplomatique, janvier 1996.

Tapscott D. 1996, The Digital Economy - Promise and Peril in the Age of Networked Intelligence, McGraw-Hill, New York.

The Straits Times 1996, Gap widening between rich and poor nations: UN report, July 171996.

UNDP (United Nations Development Programme) 1996, The Human Development Report 1996.

1 With the financial support of the Belgian Federal Office for Scientific, Technical, and Cultural Affairs (Interuniversity poles of attraction, Phase IV).

2 For example, according to the Bangemann Report technocratic vision $(1994$, p. $21, \S 2)$ : 'Communications systems combined with advanced technologies as keys to the information society.'

3 The term democracy is of course polysemic. Thus, it will not be defined here.

4 When defining its vision towards the IS, the High Level Group of Experts (1996, p. 83) acknowledges the possibility of a new concept of community.

5 On this subject, see also Tapscott (1996, p. 304), Sérusclat (1995, t. 1, pp. 69-89), Miller (1996a, p. 19) and Schuller (1996, pp. 14-15).

6 'An active citizen is responsible, autonomous, cooperating, and inventive.'

7 Amsterdam is one of the thirteen cities which participate in the European project called Telecities.

8 See, for example, Miller (1996b).

9 This group is composed of fourteen members.

10 This forum gathers 128 members from five main fields of activity: users, social groups, content and service providers, network operators, and institutions (see Com (96) 607, p. 14).

11 See Com (96) 389 final, p. 4: The Commission's Action Plan ... placed an important emphasis on social and societal questions.

$12 C f$. Article 21 (2) of the Declaration of Human Rights (such as that adopted by the United Nations General Assembly in 1948).

13 Directive 95/62/EC. See also Com (96) 419.

14 Let us remark that such a definition of universal service limited to the pipeline has also been recently adopted in the US (see FCC 96J-3).

15 See the Groupe de Lisbonne (1995), for example p. 174.

16 See also Beamish (1996), pp. 8-9.

17 Cf. Article 19 of the Declaration of Human Rights: Everyone has the right to freedom of opinion and expression; this right includes freedom to hold opinions without interference and to seek, receive and impart information and ideas through any media and regardless of frontiers. See also Article 29: In the exercise of his rights and freedom, everyone shall be subject only to such limitations which are determined by law solely for purposes of securing due recognition and respect for the rights and freedom of others and of meeting the just requirements of morality, public order and the general welfare of a democratic society. 